\title{
Synthesis of the C3-C12 Fragment of Laulimalide
}

\author{
Hyo Won Lec ${ }^{*}$ and Joong-Ycoun Hong \\ Department of Chemisty, Changbuk National University, 48 Gaeshin-dong, Cheongit, Chungbtik 36I-763, Korea \\ Received September 26, 2003
}

Key Words : Antimiototic agent, Laulimalide, RCM

The antimiototic 20-membered macrolide laulimalide (1) also known as fijanolide $B$, isolated from sea sponges such as Cacospongia moofilensis, Huatella sp. Spongia moofijens is, ${ }^{2}$ and Fasciospongia rimosa, ${ }^{3}$ shows a potent biological activity against cell lines resistant to paclitaxel or epothilones since laulimalide binds to a site of microtubules in a mode distinct from taxoids. ${ }^{4}$ The stabilization of polymerization by laulimalide leads to the inhibition of miototic spindle and apoptosis of cells.

The structure of laulimalide determined by X-ray crystallographic study was reported in the literature. ${ }^{3 a}$ The remarkable biological activity as well as its structural features of laulimalide has inspired interests of organic chemists in its synthesis. ${ }^{5-10}$ Previously we reported the synthesis of dihydropyran rings of laulimalide as a part of our synthetic effort toward laulimalide. " Herein we would like to report our synthetic efforts on the fragment C3-C I 2 of laulimalide.

Our retrosynthetic analysis of laulimalide (1) leads to two fragments of $\mathbf{2}$ and 3 . The subunit 3 can be prepared from compound $\mathbf{4}$ by exploiting the Wittig reaction on aldehyde. The dihydropyran ring of compound 4 can be provided by employing olefinic ring-closing metathesis (RCM). The subsequent transformation utilizing manipulations such as alkylation on chiral oxazolidinone and Horner-Wadsworth-Emmons reaction on side chains of $\mathbf{4}$ will provide subunit 3 .

At first, we thought the side chain at C. -9 of the dihydropyran ring of 3 could be introduced by simple elongation of the side chain of compound 4. (Eq. I) However the nucleo-

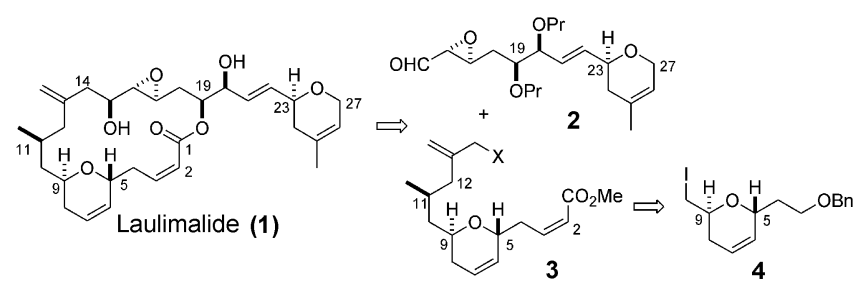

philic substitution reaction of an enolate from $(4 R, 5 S)-4-$ methyl-5-phenyl-3-propionyl-oxazolidin-2-one with iodide 7 did not yield any desired product. Likewise the reaction with a carbanion of malonate ester showed a lack of reactivity of 7 toward nucleophiles. Even when we change the iodide to a mesylate, the result was same. This behavior may be attributed to the presence of dihydropyran ring. which might render the approach of nucleophiles unfeasible. Thus we decided not to convert a dihydropyran ring prior to the elongation of backbone. This became our synthetic strategy toward subunit 3 .

Using this reaction route, compound $\mathbf{5}^{1 \text { in }}$ was converted to iodide 7 by the reduction with $\mathrm{LiAlH}_{4}$ followed by treatment with jodine and triphenylphosphine (Scheme 1). The conversion of 7 to carboxylic acid 8 of extended backbone was preformed by decarboxylation of the intermediate of

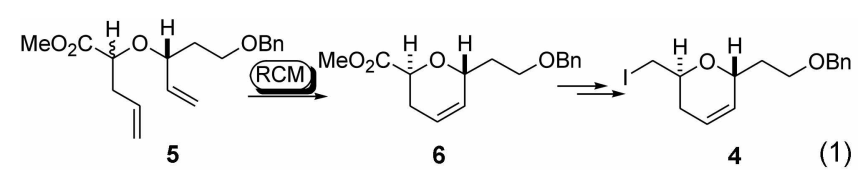<smiles>C=CCC(CCOc1ccccc1)OC(C=C)C(C)=O</smiles>

5<smiles>C=CCC(CI)OC(C=C)CCOCC</smiles>

7<smiles>C=CC[C@H](CCC(=O)O)O[C@H](C=C)CCOCc1ccccc1</smiles>

8

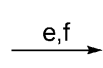<smiles>C=CCC(CC(C)C(=O)N1C(=O)OC(c2ccccc2)[C@H]1C)OC(C=C)CCOCc1ccccc1</smiles><smiles>C=C(COC)CC(C)CC1CC=CC(CCCOc2ccccc2)O1</smiles>

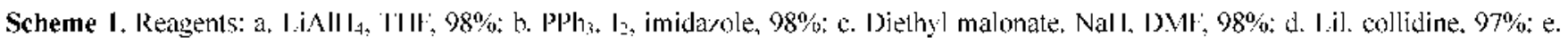

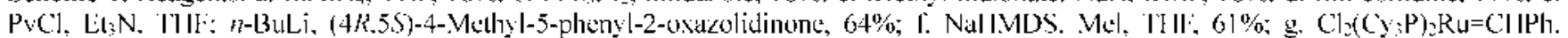

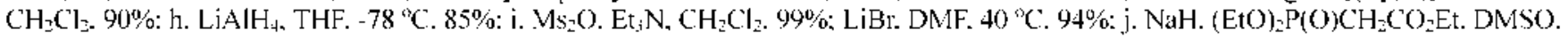
$50{ }^{\circ} \mathrm{C} .6 \mathrm{~h}: \mathrm{CH}_{2} \mathrm{O} . \mathrm{K}_{2} \mathrm{CO}_{3} .60 \%$ : k. DIBAl.. $-78^{\circ} \mathrm{C} .98 \%$ : I. MOMCl. iPr. NEt. $71 \%$. 
malonate ester using LiI. The resulting 8 was transformed to the derivative of oxazolidinone by the reaction of mixed anlydride with an enolate of chiral oxazolidinone. The methylation upon this internediate gave compound 9. Now with this compound 9 in hand, it is a time to introduce a dihydropyran ring by carrying out the RCM reaction using Grubbs catalyst. The resulting oxazolidinone 10 from RCM reaction of 9 was reduced to alcohol 11 . The next step along the sequence was the introduction of an $\alpha \beta$-unsaturated ester group using the Horner-Wadsworth-Enminons reaction. ${ }^{12}$ Thus. compound 11 was converted to a bronide intermediate via reaction of a mesylate with $\mathrm{LiBr}$. Then. this bromide was transformed to a phosphate and subsequent $i n$ sinu reaction of this intermediate with formaldehyde provided the desired unsaturated ester 12 . The reduction of an ester group followed by protection with MOM group in due course finally provided the desired compound $\mathbf{1 3}$.

In sumniary, we have reported the successful synthesis of the $\mathrm{C} 3-\mathrm{Cl} 2$ fragment of laulimalide using the introduction of a dilydropyran ring after the elongation of a side chain. Our on-going synthetic effort toward the synthesis of laulimalide will be reported in the near future.

Acknowledgement. This work was supported by Korea Science and Engineering Foundation (KOSEF-2000-1-123$002-5$ ) and in part by BK21.

\section{References}

1. Quitioa. E.: Kakao. Y.: Crews. P. J. Org. Chem. 1988. 53. 36423644 .

2. Corley: D. G.: Herb, R.: Moore. R. E.; Scheuer. P. J.; Paul. V. J. J. Org. Chem. 1988, 53. 3644-3646.

3. (a) Jeftord C. W.: Bemardinelli. G. Tanaka, J.: Higa, T. Temohedhon Lett. 1996. 37. 159-162. (b) Tanaka. T.: Higa. T.: Bernardinelli. G.: Jeftord. C. W. Chem. Lett. 1996. 25. 255-256.

4. Pryor. D. E.: O'Brate. A.: Bilcer. G.: Díaz. J. F.: Wang. Y.: Wang. Y.: Kabaki. M: Jung, M. K.: Andreu. J. M.: Ghosh. A. K. Giannakakou, P, Hamel, E. Biochemisny, 2002, 11,9109-9115.

5. Williams. D. R.: Mi, L.: Mullins, R. J.: Stites, R. E. Tetrahedron Lett. 2002. +3. $4841-4844$.

6. Crimmins. M. T.: Stanton. M. G.: Allwein. S. P. J. Ant. Chem. Soc. 2002. 12+. 5958-5959.

7. (a) Mulzer. J.: Hanbauer, M. Tetrahedron Lett. 2002, 43. 33813383. (b) Mulzer, J.: Ohler. E. Angew. Chem, Int Ed. 2001, 40. 3842-3846. (c) Enev. V. S.; Kaehlig, H.: Mulzer. J. J. An Chen. Soc. 2001. 123. 10764-10765.

8. Wender. P. A.: Hegde. S. G.: Hubbard. R. D.: Zhang. L. J. Ant. Chem. Soc. 2002. 124. 4956-4957.

9. Ghosh. A. K: Wang. Y.: Kim. J. T. J. Org. Chem 2001. 66, 89738982.

10. Paterson. I.: De Savi, C.: Tudge. M. Otg Lett 2001. 3, $3149-3152$.

11. (a) Lee. H. W.: Teong. C.-S.: Yoon. S. H.: Lee. I.-Y. C. Butl Konean Chem. Soc. 2001. 22. 791-792. (b) Lee. H. W.: Yoonl. S H.: Lee. I.-Y. C.: Chung. B. Y. Bull. Koram Chem Soc, 2001. 22. $1179-1180$

12. Vasil ev, A. A.; Engman, L.: Serebryakov. E. P. J. Chem Soc. Pahin Trans. I 2000. 221 1-2216. 